\title{
Legacy by Vindication Under the EU Succession Regulation No. 650/2012 Following the Kubicka Judgment of the ECJ
}

\author{
Piotr TereszKIEWICZ ${ }^{*} \&$ Anna Wysocka-Bar ${ }^{* *}$
}

\begin{abstract}
This article explores the question of the 'recognition' of the material effects of legacies by vindication (legatum per vindicationem), if such legacies concern the right of ownership of immovable property located in an EU Member State the law of which does not provide for such legacies to have a direct material effect, such as Germany. The authors analyse this question in the light of the first judgement issued by the Court of Justice of the European Union on the European Union Regulation No. 650/2012 on Succession and Wills, the Kubicka case (C-218/16). The article's first part provides a brief account of legacies by damnation and legacies by vindication as they are found in the substantive succession laws of EU Member States. Subsequently, key notions arising under the EU Succession Regulation No. 650/2012 with respect to the recognition of legacies by vindication, such the general principle of unity, the registry exemption, the rights in rem exception as well as the adaption of rights in rem, are discussed. The article's final part maps out the implication of the Kubicka judgment for the theory and practice of European Succession Law.
\end{abstract}

Résumé: Cet article explore la question de la « reconnaissance » des effets matériels des legs «par revindication » (legatum per vindicationem), si ces legs concernent le droit de propriété de biens immobiliers situés dans un État membre de l’Union européenne dont ne connaîssant pas l'institution du legs avec effet réel direct, comme en Allemagne. Les auteurs analysent cette question à la lumière du premier arrêt rendu par la Cour de justice de l'Union européenne sur le règlement (UE) no. 650/2012 de l'Union européenne sur les successions et testaments, l'arret Kubicka (C-218/16). La première partie de l'article décrit brièvement les legs par damnation et le legs par revindications tels qu'ils se trouvent dans le droit matériel des successions des États membres de l'UE. Par la suite, des notions clés découlant du règlement de l'UE sur les successions no 650/2012 en ce qui concerne la reconnaissance des legs "par revindication ", telles que le principe général d'unité, l'exemption de registre, l'exception des droits réels ainsi que l'adaptation des droits réels, sont discutés. La dernière partie de l'article décrit l'implication de l'arrêt Kubicka dans la théorie et la pratique du droit européen des successions.

Zusammenfassung: Dieser Artikel befasst sich mit der Frage der Anerkennung der dinglichen Wirkungen von einem Vindikationslegat (legatum per vindicationem), wenn dieses Legat das Eigentum an einer Immobilie betrifft, die in einem Mitgliedstaat belegen ist, dessen Rechtsordnung das Institut des Legats (Vermächtnisses) mit unmittelbarer dinglicher Wirkung im Zeitpunkt des Eintritts des Erbfalls nicht kennt, wie etwa Deutschland. Die

* Associate Professor in Private Law, Jagiellonian University Kraków (POLAND), Senior Research Affiliate, KU Leuven (BELGIUM). Email: piotr.tereszkiewicz@uj.edu.pl.

* Senior Lecturer in Private International Law, Jagiellonian University Kraków (POLAND). Email: anna.wysocka@uj.edu.pl. 
Autoren analysieren diese Frage unter Berücksichtigung der ersten EuGH-Entscheidung zur Europäischen Erbrechtsverordnung (EuErbVO) Nr. 650/2012, nämlich der Entscheidung in der Rechtssache Kubicka (C-218/16). Der erste Teil des Artikels enthält einen kurzen Überblick über die Regelung der Vindikations- und Damnationslegate in nationalen Erbrechten der EU-Mitgliedstaaten. Darauffolgend sind einige mit Blick auf die Anerkennung der dinglichen Wirkungen von Vindikationslegaten grundlegende Institute der EuErbVO besprochen, wie etwa der Grundsatz der Nachlasseinheit, die Bereichsausnahme des Registerstatutes, die Bereichsausnahme für die Art der dinglichen Rechte sowie die Frage der Anpassung der dinglichen Rechte. Zum Abschluss werden die Auswirkungen des Kubicka-Entscheids für die Theorie und Praxis des Europäischen Erbrechts untersucht.

Keywords: Regulation $n^{\circ}$ 650/2012, Applicable law, Legacy by vindication, Legacy by damnation, Succession Law, Register, Adaptation, European Certificate of Succession.

Mots-clés: Règlement $n^{\circ}$ 650/2012, Loi applicable, Legs “par revendication”, Legs ordinaire, Droit des succession, Registre, Adaptation, Certificat successoral européen.

Schlüsselwörter: Verordnung Nr. 650/2012, anzuwendendes Recht, Vindikationslegat, Damnationslegat, Erbrecht, Register, Anpassung, Europäisches Nachlasszeugnisses.

\section{Introduction}

1. On 12 October 2017, after due consideration of the opinion of the Advocate General Yves Bott (hereafter 'AG's opinion'), the Court of Justice of the European Union (hereafter 'ECJ') issued the judgement in case C-218/16 (Kubicka). This judgment constitutes an answer to the first request for a preliminary ruling related to the Succession Regulation (hereafter abbreviated as SR). ${ }^{1}$

2. The SR is applied by EU Member States, with the exception of the UK, Ireland and Denmark, as of 17 August 2015 to the succession cases of persons deceased starting from that day (Articles 83(1) and $84 \mathrm{SR}$ ). In accordance with the SR, the law applicable to succession (lex successionis) is the law of the habitual residence of the deceased at the time of death, subject to the operation of the escape (closer connection) clause (Article $21 \mathrm{SR}$ ). A natural person is attributed with the competence to designate the law applicable to his or her succession, however this choice is limited to the national law of the person deceased at the time of making the choice or at the time of death (Article 22 SR). Simultaneously, the SR contains separate rules relating to specific issues of the succession case, namely the material and formal validity of the dispositions of property upon death. The law applicable to the material validity of the disposition of property upon death, if no choice of applicable law was made, is in

1 Reg No. 650/2012 of 4 July 2012 on jurisdiction, applicable law, recognition and enforcement of decisions and acceptance and enforcement of authentic instruments in matters of succession and on the creation of a European Certificate of Succession (hereafter Succession Regulation or SR), eur-lex.europa.eu/legal-content/ALL/?uri=celex\%3A32012R0650. 
general hypothetical succession law, i.e. the law which would have been applicable if the testator had died on the day on which the disposition was made (Article 25 SR - agreements as to succession and Article $24 \mathrm{SR}$ - other dispositions of property upon death, for example wills). By contrast, formal validity of dispositions of property upon death other than agreements as to succession is subject to two (not so) different regimes depending on the EU Member State itself. In EU Member States which are parties to the Convention of 5 October 1961 on the Conflicts of Laws Relating to the Form of Testamentary Dispositions, formal validity of the above-mentioned dispositions is still governed by this convention (Article 75(1) SR). In the remaining EU Member States (and in all Member States with respect to agreements as to succession), the question of formal validity is governed by the SR and its Article 27, which was strongly inspired by the favour validitatis principle of the said Hague Convention. ${ }^{2}$ The SR provides for non-exhaustive lists of issues which should be governed by the law applicable to - respectively - succession (lex successionis - Article $23 \mathrm{SR}$ ), the material validity of dispositions of property upon death (Article $26 \mathrm{SR}$ ) and their formal validity (Article 27(3) SR).

3. The request for a preliminary ruling relating to the SR, introduced by a municipal court in Poland, concerns the legal effects of a legacy by vindication (legatum per vindicationem) made under Polish law, where Polish law is the law applicable to succession in accordance with the SR, in case an immovable property subject to this legacy is located in another EU Member State, the substantive law of which does not provide for such a legacy.

\section{The Facts of the Case in Question}

4. The facts of the case in question deserve close attention. Ms Kubicka, a Polish citizen, is married to a German citizen and resides in Frankfurt an der Oder (Germany). The spouses are joint owners (with 50\% shares each) of an immovable property located in Frankfurt an der Oder, on which their family house is built. Ms Kubicka approached a notary in Slubice (Poland), as she intended to draft a will choosing Polish law as applicable (based on Article 22 SR) and include in her will a legacy by vindication (pl. zapis windykacyjny) in favour of her husband concerning her share of ownership of the jointly owned immovable property. As far as the remainder of the assets belonging to her estate is concerned, Ms Kubicka intends them to be inherited in accordance with the statutory order of inheritance, whereby

2 A. Bonomi, 'Conférence de la Haye et Union Européenne - synergies dans le domaine du droit des successions', in A Commitment to Private International Law. Essays in honour of Hans van Loon/ Un engagement au service du droit international privé. Mélanges en l'honneur de Hans van Loon, The Permanent Bureau of the Hague Conference on Private International Law/Le Bureau Permanent de la Conférence de la Haye de droit international privé (Cambridge-AntwerpPortland: Intersentia 2013), p (69) at 71-72. 
her husband and children would inherit them in equal shares. Regarding her share of ownership of the jointly held immovable property, Ms Kubicka expressly ruled out recourse to an ordinary legacy (pl. zapis zwykty) under Polish law which would grant her husband a claim against the estate. An ordinary legacy, as Ms Kubicka claimed, would entail difficulties as regards the representation of her minor children as heirs as well as would cause additional costs.

5. The notary refused to draw up a will that would include legatum per vindicationem concerning an immovable property located in Germany. The refusal to draw up a will was justified with the allegation that foreign legatum per vindicationem will be considered in Germany to be legatum per damnationem by means of 'adaptation' under Article 31 SR. Such an interpretation is justified in the light of the explanatory memorandum of the German law adjusting national law provisions to the $\mathrm{EU} \mathrm{SR}^{3}$ and case-law (see below). As a result, drafting a will in accordance with Ms Kubicka's wish will not allow her to fulfil her wish that upon her death her husband should acquire ex lege the ownership of the immovable property located in Germany, without any additional difficulties or costs.

6. Ms Kubicka appealed the decision of the notary to the municipal court of Gorzów Wielkopolski, emphasizing that the German standpoint on a legacy by vindication is not necessarily shared by legal scholarship in other Member States. Hence, the court assumed then that there is a need for the ECJ to provide an interpretation of the EU SR. The preliminary question asked by the Sad Okregowy w Gorzowie Wielkopolskim reads as follows: 'Must Article 1(2)(k), Article 1(2)(1) and Article 31 of the SR be interpreted as permitting refusal to recognize the material effects of a legacy by vindication (legatum per vindicationem), as provided for by succession law, if that legacy concerns the right of ownership of immovable property located in a Member State the law of which does not provide for legacies having direct material effect?' ECJ, as it was suggested in the Advocate General's opinion, answered in the negative, laying down its interpretation of the relevant provisions of the SR.

\section{Legatum per vindicationem in Substantive Succession Law}

7. To begin with, an obvious remark should be made. The EU SR constitutes the fruit of the unification of international succession laws of EU Member States, i.e. unification of the rules on law applicable to succession. The substantive succession laws of the EU Member States are not subject to unification as the EU lacks appropriate competence in this respect. ${ }^{4}$ The uncertainty that gave rise to Ms

3 Internationales Erbrechtsverfahrensgesetz, 29. Juni 2015, Bundesgesetzblatt Teil I, Nr. 26, S. 1042, https://www.bgbl.de/xaver/bgbl/start.xav?start=\%2F\%2F*\%5B\%40attr_id\% 3D’bgbl115s1042.pdf'\%5D\#__bgbl__\%2F\%2F*\%5B\%40attr_id\%3D\%27bgbl115s1042.pdf\%27\% 5D__1543688853304 (accessed 1 December 2018).

Cf. Article 2 Succession Regulation. 
Kubicka's case flows from the fact that the substantive succession laws of the EU Member States differ from one another in numerous aspects, the institute of legatum per vindicationem being a major example.

8. The concept of legacy is known to most contemporary laws of succession. It goes back to Roman law, where Justinian's Institutes defined a legacy as a gift from a dead person. ${ }^{5}$ Legacy is a disposal at the cost of the inheritance (estate) based on a unilateral act of the testator upon death, and aimed at ensuring that the person indicated obtains certain rights. The person indicated does not become heir, but a legatee, the recipient of the legacy. ${ }^{6}$ Two major legal types of legacies can be identified.

9. First, there are legacies that give rise to an obligation, namely legacies by damnation. Under this legal form, a testator obliges an heir (or a legatee), to make a specific property performance for the benefit of a given person, a legatee. ${ }^{7} \mathrm{~A}$ legatee acquires a personal claim against the heir(s) for the transfer of the asset devised to him or her as outlined in the will. This means that the title to the asset has to be transferred by way of an inter vivos transaction between the heir(s) and the legatee in accordance with the applicable rules of property law. ${ }^{8}$ The legatee becomes a creditor of the estate, his or her legal position being weaker than that of an heir. ${ }^{9}$ Legacy by damnation is the only form of legacy allowed in certain national laws of succession, in particular Germany, where the case in question caused important controversy, but also in Austria and Switzerland. ${ }^{10}$ The German Civil Code attaches central importance to the principle of universality of succession (Universalsukzession), which entails among other things the inadmissibility of legatum per vindcationem. ${ }^{11}$ It follows that in accordance with $\S 2174$ BGB

5 I. 2.20.1, cf. F. Longchamps DE Bérier, Law of Succession. Roman Legal Framework and Comparative Law Perspective (Warszawa: Wolters Kluwer 2011), pp 193-194; L. SAlomon, 'The Acquisition of Possession in Legacies per Vindicationem in Classical Roman Law and its Influence in the Modern Civil Codes', Roman Legal Tradition 2006(3), p 65.

6 In most systems it is possible that a legatee is also appointed as a successor.

7 Cf. Article 968 Polish Civil Code; § 2174 German Civil Code.

8 D. LeIPold, Erbrecht (Tübingen: Mohr Siebeck 19th edn 2012), p 318; D. Solomon, 'The boundaries of the law applicable to succession', 18. APFUZ (Anali Pravnog Fakulteta Univerziteta $u$ Zenici) 2016, p (193) at 212.

9 K. Lange, Erbrecht (München: C.H. Beck, 2nd edn 2017), p 486; J. PiąTowsKi \& B. Kordasiewicz, Prawo spadkowe. Zarys wyktadu (Law of Succession. Outline) (Warszawa: LexisNexis, 7th edn 2011), p 134.

10 See $\S 684$ Austrian Civil Code (ABGB) and Article 484 Swiss Civil Code (ZGB).

11 D. LEIPOLD, 'Wandlungen in den Grundlagen des Erbrechts', 180. AcP (Archiv für die civilistische Praxis) 1980, p (160) at 209, emphasizes that German law admitted legacy per vindicationem prior to the enactment of the Civil Code of 1896 (Bürgerliches Gesetzbuch); see also K. MuscheLER, Erbrecht (Tübingen: Mohr Siebeck 2010), p 1297; K.W. Lange, Erbrecht (München: C.H. Beck, 2nd edn 2017), pp 228-229. 
(Bürgerliches Gesetzbuch) only a legacy by damnation (Damnationslegat) is allowed. ${ }^{12}$ This means that German law does not allow the legacy to transfer ipso iure ownership of an asset to a legatee. ${ }^{13}$ Polish law of succession, equally relevant for the case in question, shared this position until as recently as $2011 .^{14}$

10. Second, there are legacies that transfer the property to the legatee, called legacies by vindication (legatum per vindicationem). The major effect of the legacy by vindication is that it vests in the legatee the ownership of the thing immediately upon succession. It follows that unlike the legacy by damnation, the legacy by vindication does not constitute a source of obligation between a legatee and the heir, but it produces a direct and immediate effect at the moment of the testator's death. ${ }^{15}$ The legacy by vindication provides for an exception from the principle of the universality of succession. It enables the testator to transfer specific items or rights directly to the legatee, taking them out of the scope of the estate and subjecting them to a singular succession. ${ }^{16}$ Hence, the legal position of the legatee by vindication is much stronger than that of a legatee by damnation. The legatee by vindication acquires his or her right at the very moment of the testator's death (the opening of the succession) and is not dependent on the performance of the obligation by the heir, as is the case in legacies by damnation. Legacy by vindication is known in a number of European succession laws, in particular in Belgium, France, Greece, Italy, Luxemburg, Portugal and Spain. ${ }^{17}$ Poland introduced the legatum per vindicationem in its law of succession as recently as $2011 .{ }^{18}$ Under the new Polish law, while a legacy by damnation is considered to be an ordinary form of legacy, a legacy by vindication could be made in a notarial will, in which the testator could decide that the person indicated would acquire the object of the legacy on the opening of the succession. Most importantly, certain movables or immovable

12 D. LEIPOLD, Erbrecht, p 318. For a recent study examining the perspective of introducing legacy by vindication into German inheritance law see D. TıETz, Das Vindikationslegat (Tübingen: Mohr Siebeck 2017).

13 D. LeIPOLD, 180. AcP 1980, p (160) at 209.

14 See K. Osajda, 'The New Polish Regulation on Legatum per Vindicationem: A New Solution for Old Problems', 20. ZEuP (Zeitschrift für Europäisches Privatrecht) 2012, p 484; W. ŻuKowsKI, 'Proposed Amendments to the Polish Succession Law Concerning Legacies and Donations', in C. von Bar \& A. Wudarski (eds), Deutschland und Polen in der europäischen Rechtsgemeinschaft (München: Sellier 2012), p 719.

15 K. Osajda, 20. ZEuP 2012, p (484) at 486.

16 F. LONGCHAMPS DE BÉRIER, Law of Succession, p 202.

17 F. Longchamps de Bérier, Law of Succession, p 202; J.P. Schmidt, 'Die kollisionsrechtliche Behandlung dinglich wirkender Vermächtnisse. Ein Prüfstein für Grundfragen des internationalen und des materiellen Privatrechts', 77. RabelsZ (Rabels Zeitschrift für ausländisches und internationales Privatrecht) 2013, p (1) at 4; see also country reports in R. Süss, Erbrecht in Europa (München: C.H. Beck 3rd edn 2016).

18 The Act of 18 March 2011 on the amendments to the Civil Code; see K. OsaJda, 20. ZEuP 2012, $\mathrm{p}(484)$ at 485 . 
property or rights may be transferred directly to the beneficiaries (Article $981^{1}$ Civil Code). It is important to note that the legatee acquires his or her right directly from the deceased, and not through the heir.

11. Clearly the choice of the legacy form is imbedded into the general system of liability in the context of inheritance in a given legal system. ${ }^{19}$ Where a specific asset automatically leaves the estate upon the death of the testator as a legacy by vindication, it may not be available to satisfy claims against the estate. ${ }^{20}$ Under the new Polish rules on legacies by vindication, legatees by vindication are in principle liable for succession debts. ${ }^{21}$ However, the legatee liability is limited to the value of the objects of his or her legacy, calculated at the time of the legator's death and according to prices prevailing at the same time (Art. $1034^{3}$ Civil Code).

\section{Legacy per Vindication in Private International Law}

12. The diverging positions of Germanic legal systems on the one hand, and national succession laws permitting legacy by vindication (such as the Polish or French) on the other, give rise to a major legal issue where a legacy by vindication arising under a domestic law of succession concerns property located in Germany. The position of the German judiciary, which the Polish notary invoked in order to justify his refusal to draw up a will comprising a legacy by vindication, goes back to a case decided by the German Supreme Court (BGH) in 1994. ${ }^{22}$ The deceased had his habitual residence in Colombia and had bequeathed by will full ownership to an immovable property located in Germany. Applying the German private international law, the German Supreme Court held that giving effect to a foreign Vindikationslegat would be in violation of the numerus clausus of the possible modi of acquiring property under German property law. ${ }^{23}$ Further, the Court held, the law applicable to succession was invoked only to determine the beneficiaries of the will and the

Cf. the examples of different national solutions J.P. SсHмIDT, 77. RabelsZ 2013, p (1) at 12-13. Rightly D. Solomon, 18. APFUZ 2016, p (193) at 214.

21 J. Piątowski \& B. Kordasiewicz, Prawo spadkowe, p 184; K. Osajda, 20. ZEuP 2012, p (484) at 494-495.

22 Bundesgerichtshof (BGH) 28 September 1994, IV ZR 95/93, FamRZ (Familienrechtszeitschrift) 1994, p 1585; followed by Kammergericht (KG) 26 Februar 2008, NJW-RR (Neue Juristische Wochenschrift-Rechtsprechungs-Report) 2008, p 1109. In German scholarship see among others P. Gröschler, 'BGH, 28. 9. 1994 - IV ZR 95/93. Ausländisches Vindikationslegat über im Inland belegene Sachen', 51. JZ (JuristenZeitung) 1996, pp 1028-1032; Y. Nishitani, 'Ausländische Vindikationslegate und das deutsche Erbrecht - unter besonderer Berücksichtigung des japanischen Rechts', 18. IPRax (Praxis des Internationalen Privat- und Verfahrensrechts) 1998, pp 74-79; R. Süss, 'Das Vindikationslegat im Internationalen Privatrecht', 65. RabelsZ 2001, pp 245-263.

BGH of 28 September 1994, FamRZ 1994, p 1585. 
assets to which they would be entitled. ${ }^{24}$ The question as to how the title is to be transferred was deemed to be subject to German law, given that the real property in question was situated in Germany. As a result, a foreign (non-German) legacy by vindication of immovable property located in Germany should be treated as a legacy by damnation, conferring on the legatee the claim to be transferred the title to the property rather than the title itself. ${ }^{25}$

13. The position adopted in the Supreme Court's decision of 1994 appears to have shaped the widely held view of German jurisprudence and legal doctrine regarding the effects of foreign legacies by vindication concerning property located in Germany. Most importantly, this view has continued to be endorsed in the scholarship under the SR. ${ }^{26}$ It is pointed out that in light of Article 1 (2) (1) SR to the extent that rights have to be recorded in a register, the law of the country of registration will not only apply to the formal requirements of registration but will also govern the substantive requirements for the creation or transfer of a right that is subject to registration. ${ }^{27}$ But a differing position has also emerged in the German scholarship under the SR, claiming that the registry exemption of Article 1 (2)(1) SR must be read to refer only to the procedure of recording rights in the register and the effects of such recording with regard to third parties. $^{28}$

14. Looking from the Polish perspective, the prevailing view in the scholarship used to hold that the effectiveness of the legatum per vindicationem should be subjected cumulatively to the lex successionis and the law applicable to rights in rem (lex rei sitae). Hence, a legacy by vindication would transfer the ownership to a legatee ex lege upon the death of the testator only when such a direct effect was

See also D. Solomon, 18. APFUZ 2016, p (193) at 212.

25 See J.P. Sснмidt, 77. RabelsZ 2013, p (1) at 6, where a detailed account of German scholarship is provided. The position under German private international law prior to the EU Succession Regulation is followed by P. Lagarde, in U. Bergquist, D. Damascelli, R. Frimston, P. Lagarde, F. Odersky \& B. Reinhartz, EU Regulation on Succession and Wills: Commentary (Köln: Otto Schmidt 2015), p 167.

26 In German literature for instance J. MüLler-Lukoscheк, Die neue EU-Erbrechtsverordnung. Leitfaden mit Erläuterungen für die notarielle Praxis (Berlin: Deutscher Notarverlag 2013), para. 83; in commentaries on the Succession Regulation P. LAGARDE, in EU Regulation, p 167, drawing explicitly on BGH of 28 September 1994, FamRZ 1994, p 1585; A. MaChNiKowsKA, in M. Załucki (ed.), Unijne rozporzadzenie spadkowe $\mathrm{nr}$ 650/2012. Komentarz (Sucession Regulation EU 650/ 2012. A Commentary) (Warszawa: C.H. Beck 2015), p 205.

27 See C. Hertel, 'Die Abgrenzung des Erbstatuts vom Sachstatut und vom Gesellschaftsstatut', in A. Dutta \& S. Herrler (eds), Die Europäische Erbrechtsverordnung (München: C.H. Beck, 2014), $\mathrm{p}(85)$ at 99.

28 See A. DutTA, in J. v. Hein, Münchener Kommentar zum Bürgerlichen Gesetzbuch: BGB, Vol. 12: Internationales Privatecht I (München: C.H. Beck 6th edn 2015), Art. 1 Succession Regulation, paras 31 et seq. 
provided for also in the lex rei sitae. ${ }^{29}$ As time passed by, this standpoint evolved and it was suggested that both legacy by damnation and legacy by vindication, including its direct effect, should be governed solely by the lex successionis, including the cases where the object of the legacy is located in Poland. ${ }^{30}$ Hence, the effects of the legacy by vindication of the property located in Poland should not be jeopardized by the fact that this institution was (at that time) unknown to Polish substantive succession law. It was, however, admitted that once the object of the legacy by vindication is an immovable property located in Poland, in practice it might be impossible to register such a transfer of ownership in the land register. ${ }^{31}$ The introduction of the legacy by vindication to Polish substantive law coincided with the EU works on the SR. Hence, building on the 'liberalized' approach, it was suggested that under the SR the question of the transfer of property to legatees should be governed solely by the lex successionis. ${ }^{32}$

15. As indicated above, the substantive inheritance laws of the EU Member States differ significantly as regards the admissibility of legacy by vindication. Furthermore, the approach towards legacy by vindication, which a legal system adopts in its substantive law of inheritance, appears to influence the approach towards this institute which this legal system takes in the national conflict of laws provisions. German law provides a useful example in this respect. This could be tolerated in the past (to be more precise, when it comes to succession cases of persons deceased before 17 August 2017), when EU Member States applied their own domestic conflict of laws provisions. Nowadays (or rather, when it comes to succession cases of persons deceased starting from 17 August 2017), as the international succession law of EU Member States is unified, such divergent approaches are simply inadmissible. It is quite obvious that SR is subject to autonomous interpretation, meaning that its provisions should be understood in the same manner in every Member State and consequently, should not be read solely through the lens of domestic law, no matter if substantive or private international. ${ }^{33}$ Taking into account these divergent standpoints, it seems that the request for a preliminary ruling in Kubicka case was well justified.

29 M. PAzDAn, 'Kolizyjnoprawna problematyka nabycia spadku (Acquisition of estate in private international law)', 23. SC (Studia Cywilistyczne) 1974, p (121) at 170-171.

30 J. Górecki, 'Zapis testamentowy w prawie kolizyjnym (Legacy in private international law)', 5. PPPM (Problemy Prawa Prywatnego Międzynarodowego) 2009, p (131) at 145.

31 J. Górecki, 5. PPPM 2009, p 145.

32 M. MARgońSKI, 'Skutki rzeczowe zapisu windykacyjnego na tle rozporządzenia spadkowego (Property law effects of legacy by vindication under the Succession Regulation)', in M. Pazdan (ed.), Nowe europejskie prawo spadkowe (New European law of succession) (Warszawa: Wolters Kluwer 2015), pp 205-227 at 215.

33 H. Pamboukis, in H. Pamboukis (ed.), EU Succession Regulation No 650/2012. A Commentary (Athens: Nomiki Bibliothiki/C.H. Beck/Hart/Nomos 2017), p 12. 


\section{The Position of the ECJ}

\subsection{Introduction}

16. It is submitted that the judgment of the ECJ should be analysed in four steps, as there are clearly four major issues discussed by the Court. First, the unity principle as it is described in the Recitals of the $\mathrm{EU} \mathrm{SR}^{34}$ and can be inferred from its provisions, for example, Article 21(1) SR. Second, the rights in rem exemption (Article $1(2)(\mathrm{g}) \mathrm{SR}$ ). Third, the provision on the adaptation of rights in rem (Article 31). Fourth, the registry exemption (Article 1(2)(1) SR). The interpretation of the above provisions should take into account the creation by the SR of a new EU legal instrument, namely the European Certificate of Succession ${ }^{35}$ (Chapter 6 of the SR). Additionally, while analysing the provisions of the SR, one should not forget that it constitutes a part of EU law and, therefore, general considerations behind the adoption of the SR, as presented in Recital 7, must serve as guidance. First, the proper functioning of the EU internal market requires removal of any obstacles to the free movement of persons who, in the past (i.e. with respect to the succession cases of persons deceased before 17 August 2017) used to face difficulties in asserting their rights in succession cases having cross-border implications. The SR is a tool designed in order to remove these obstacles. Second, the existence of the European Area of Justice should afford citizens with the possibility to organize their succession in advance. Thirdly, the rights of beneficiaries must be effectively guaranteed.

\subsection{The Succession Case Within the Meaning of the SR}

17. Before analysing the reasoning of the ECJ, it is important to consider the meaning of 'succession' within the SR. In accordance with Article 1(1) SR, this Regulation applies to succession to the estates of deceased persons. Article 3(1)(a) SR clarifies that this term means succession to the estate of a deceased person and covers all forms of the transfer of assets, rights and obligations by reason of death, whether by way of a voluntary transfer under a disposition of property upon death or a transfer through intestate succession. This definition seems to be in line with the understanding of succession in the substantive laws of EU Member States. ${ }^{36}$ The preamble in Recital 9 states that the scope of the regulation 'should include all civil-law aspects of succession to the estate of a deceased person'. The understanding of the notion of succession is reflected also in Article 3(1)(d) SR, which defines the

34 On the legal significance of the preamble to the Succession Regulation see H. PAmboukis, in $E U$ Succession Regulation, pp 12-13.

35 On which see C. Hertel, 'European Certificate of Succession-Content, Issue and Effects', 15. ERA Forum 2014(3), pp 393-407.

36 P. Wautelet, in A. Bonomi \& P. Wautelet, Le droit européen des successions. Commentaire du Règlement $n^{\circ} 650 / 2012$ du 4 juillet 2012 (Bruxelles: Bruylant 2013), p 72. 
dispositions of property upon death and Article 23 SR which lists (non-exhaustively) issues governed by the law applicable to succession (lex successionis). The boundaries of the SR are drawn in Article 1(2) which enumerates the issues left outside its scope. This indicates that the SR has a relatively broad scope of application and covers all of the issues forming the substantive succession laws of the EU Member States (with minor exceptions, for example, the formal validity of dispositions of property upon death made orally - Article 1(2)(f)) SR. ${ }^{37}$ Hence, the case of Ms Kubicka, who wants to include a legacy in her testament to make sure that her husband becomes an owner of the marital house upon her death, concerns succession. ${ }^{38}$

\subsection{The Principle of Unity in the SR}

18. In paragraph 43 of its judgement, ECJ underlines that the SR establishes the principle of unity. The analysis of this principle might begin with the observation that it has two, interrelated aspects, a territorial and a functional one ${ }^{39}$ (which are also, respectively, referred to as horizontal and vertical). ${ }^{40}$ In accordance with Article 21(1) $\mathrm{SR}$, the lex successionis is designated with the single, personal connecting factor of the habitual residence of the deceased, subject to an escape clause, which may also designate one single substantive succession law as applicable. Similarly, Article 22 SR allows only for the national law to be chosen by the deceased as applicable. Hence, again a single, personal connecting factor of nationality is used. As a result the authority dealing with the succession case will ascertain the law applicable to succession based on the circumstances concerning the deceased, i.e. habitual residence, nationality or 'closer connection'. In general, the location of assets, including immovable property, remains irrelevant when it comes to designating the lex successionis. ${ }^{41}$ Interestingly, the location of assets may have an influence when asserting the habitual residence of the deceased (Recital $24 \mathrm{SR}$ ). The whole estate, including immovable property located in different countries is, therefore, subject to inheritance in accordance with one single substantive succession law. Hence, substantive law, which constitutes the lex successionis, will not necessarily coincide with the lex rei sitae. The territorial (horizontal) aspect of the principle of unity is explained in Recital 37 of

P. Wautelet, in Le droit européen des successions, p 72.

Based on the distinction between territorial and function scission as made by M. FerID, 'Le rattachement autonome de la transmission successorale en droit international privé', 142. Recueil des Cours (The Hague Academy Collected Courses/Recueil des Cours de l'Académie de la Haye) 1974, p (85) at 95, and also L. HAOPEI, 'Some Recent Developments in the Conflict of Laws of Successions', 224. Recueil des Cours (The Hague Academy Collected Courses/Recueil des Cours de l'Académie de la Haye) 1990, p (19) at 21.

40 P. Lagarde, in U. Bergquist, D. Damascelli, R. Frimston, P. Lagarde, F. Odersky \& B. Reinhartz, Commentaire du Règlement Européen sur les Successions (Paris: Dalloz 2015), pp 7-8.

41 A. Bonomi, in Le droit européen des successions, p 365; D. Solomon, 18. APFUZ 2016, p 196. 
the SR, which states that 'in order to avoid the fragmentation of the succession, that law should govern the succession as a whole, that is to say, all of the property forming part of the estate, irrespective of the nature of the assets and regardless of whether the assets are located in another Member State or in a third State'. The expression 'fragmentation' means what used to be called 'scission' in the scholarship of private international law. ${ }^{42}$ The scission may occur as a result of the law applicable to succession being designated by two separate connecting factors, in practice a personal one (nationality, domicile, habitual residence) when it comes to movables and a territorial one (lex rei sitae) when it comes to immovable property. If these two connecting factors point to at least two different countries, scission occurs, meaning that the estate is divided into two (or more) separate parts governed by two (or more) separate substantive succession laws. To summarize, the territorial aspect of the principle of unity means that it is the single lex successionis that governs succession without any intervention of the substantive succession law of another state, namely the state where the property is located. ${ }^{43}$

19. Once the lex successionis is determined, Article 23 SR lists non-exhaustively the issues which it governs. For example, in accordance with Article 23(2)(b) SR, the lex successionis decides on 'the determination of the beneficiaries, of their respective shares and of the obligations which may be imposed on them by the deceased, and the determination of other succession rights'. Recital 47 SR makes it clear that the term 'beneficiaries' covers both heirs and legatees, even though 'the legal position of legatees is not the same under all laws'. ${ }^{44}$ Article 23(2)(e) SR indicates that the lex successionis governs also 'the transfer to the heirs and, as the case may be, to the legatees of the assets, rights and obligations forming part of the estate'. The above point seems to make it clear that the transfer of assets to legatees is governed by the lex successionis. One may try to argue that the expression 'as the case may be' refers to situations where the lex rei sitae provides for such a transfer. However, it seems much more convincing that this expression refers simply to situations where the testator in the disposition of property upon death indeed included a legacy. The functional (vertical) aspect of the principle of unity means that the lex successionis governs all aspects of the succession case, including the transfer of the ownership of the assets. ${ }^{45}$ The importance of that principle is expressed in Recital $42 \mathrm{SR}$, according to which the lex successionis

On scission see A. Bonomi, 'Successions Interntionales: Conflits de lois et de jurisdictions', 350. Recueil des Cours (The Hague Academy Collected Courses/Recueil des Cours de l'Académie de la Haye) 2011, p (71) at 121-135.

43 A. Davi, in A. Calavo-Caravaca, A. Davi \& H.-P. Mansel (eds), The EU Succession Regulation. A Commentary (Cambridge: Cambridge University Press 2016), p 37.

44 See C. Baldus, 'Erbe und Vermächtnisnehmer nach der Erbrechtsverordnung', 9. GPR (Gemeinschaftsprivatrecht) 2012, pp 312-315.

45 A. DAVI, in The EU Succession Regulation, p 37. 
'should govern the succession from the opening of the succession to the transfer of ownership of the assets forming part of the estate to the beneficiaries as determined by that law'. Further, Recital 15 puts it straightforwardly that the transfer by succession of a right in immovable property operates 'as provided for in the law applicable to the succession'. To conclude, no aspect of the succession, including the transfer of ownership of the assets forming part of the estate, should be governed by any other substantive succession law than the lex successionis.

20. Both aspects of the unity principle matter in Ms Kubicka case. On the one hand, the territorial aspect of this principle objects to the different treatment of particular assets of the estate as a consequence of their physical location. In this sense, applying German law to the succession case of Ms Kubicka would constitute an unwelcomed reflection of the lex rei sitae principle that used to be applied in the past to the succession of immovable property in some EU Member States. On the other hand, the functional aspect of the unity principle objects to the application of any other substantive law than the lex successionis (as determined pursuant to Article 21 or Article $22 \mathrm{SR}$ ) to the transfer of ownership of the assets to the beneficiaries, including legatees. The above means that with respect to the legacy by vindication the transfer of ownership in the immovable property to the legatee should operate in accordance with the lex successionis, without the need for the intervention of the lex rei sitae.

21. Clearly the unity principle is not absolute. As regards its functional dimension, this principle admits limitations, as certain aspects of the succession case, namely the material and formal validity of the disposition of property upon death, might be governed by a substantive law other than the lex successionis (Articles 24$27 \mathrm{SR}$ ). Additionally, in its territorial aspect it also experiences limitations in some instances, in particular when the immovable property (or any other asset) is located in a third state, whereas the court of one of the EU Member States has jurisdiction only with respect to assets located on its territory (Article 10(2) SR). Also the application of the provision on the mandatory rules of the lex rei sitae constitutes the exception to the principle of unity (Article $30 \mathrm{SR}$ ). It is clear that none of these exceptions to the unity principle might have influence on the outcome of the Kubicka case, as the case does not concern the formal and material validity of the disposition of property upon death, the immovable property in question is located in EU Member States and not in a third state and the marital house does not constitute a 'special category of assets' to which Article 30 SR could apply.

22. The question remains as to whether any other provision of the SR could support the conclusion that the legacy by vindication governed by Polish law being the lex successionis should be deprived of its effectiveness in another EU Member State, in which substantive succession law does not provide for legacy by vindication. In this context, the preliminary question draws the attention of the ECJ to Article 1(2)(k), Article 1(2)(l) and Article 31, as the SR excludes from its scope of application two important matters: a) the nature of rights in rem and b) 
any recording in a register of rights in immoveable or moveable property, including the legal requirements for such a recording and the effects of recording or failing to record such rights in a register. These exceptions will be examined below, together with the provision on the adaptation of rights in rem closely related to the first of the above mentioned exemptions.

\subsection{The Rights in rem Exemption}

23. In general, the rights in rem are governed by the law of the place where the property is located (lex rei sitae). ${ }^{46}$ Since the succession law is all about, inter alia, rights in rem and their transfer to beneficiaries, the question arises as to the boundaries between the scope of the application of the lex successionis and the law applicable to rights in rem. ${ }^{47}$ This is addressed by the Article $1(2)(\mathrm{k})$ SR, which excludes the nature of rights in rem from the scope of the SR. The Recital 15 explains that the SR should allow for "the creation or the transfer by succession of a right in immovable or movable property as provided for in the law applicable to the succession'. At the same time, the Recital 15 underlines that the SR should 'not affect the limited number (numerus clausus) of rights in rem known in the national law of some Member States. A Member State should not be required to recognize a right in rem relating to property located in that Member State if the right in rem in question is not known in its law'. Further explanation is to be found in the Explanatory Memorandum, ${ }^{48}$ which stated that the Regulation applies to 'the acquisition of a right in rem relating to inherited property, but not to the content of such a right'. The Explanatory Memorandum makes clear that the SR may not affect the numerus clausus of rights in rem, the classification of property and rights, and the determination of the prerogatives of the holder of such rights. As an example of the right in rem known to some Member States and unknown to others, the Explanatory Memorandum takes the right of usufruct (usus fructus). Sticking to this example, it might be assumed that the application of the lex successionis may not result in a situation when a beneficiary obtains a right of usufruct over an immovable property located in the Member State, which does not know such an institution. The above suggests that the lex rei sitae decides on whether a given right in rem exists and whether and how it can be exercised, whereas the transfer of the right in rem existing under the lex rei sitae by way of succession is included in the scope of the SR and governed by the lex successionis. ${ }^{49}$

G. NiKolaidis, in EU Succession Regulation, p 50.

See Z. Crespi Reghizzi, 'Succession and Property Rights in EU Regulation No 650/2012', 3. Rivista di diritto internationale privato e processuale 2017, p (633) at 634.

Proposal for a Regulation of the European Parliament and of the Council on jurisdiction, applicable law, recognition and enforcement of decisions and authentic instruments in matters of succession and the creation of a European Certificate of Succession, eur-lex.europa.eu/legalcontent/en/TXT/?uri=CELEX\%3A52009PC0154 (accessed: 1 December 2018).

G. NiKolaidis, in EU Succession Regulation, p 52. 
24. The Explanatory Memorandum underlines that Article $1(2)(\mathrm{k})$ SR “does not apply to the transfer of a right in rem recognized by the Member State in which the inherited property is located'. In the case of Ms Kubicka the right in rem in question is the right of ownership of an immovable property. Hence, it concerns a right in rem recognized in Germany. The issue not known to German law is not the right in rem itself, but rather the method of its transfer to the legatee upon the death of the deceased. In this context the application of the lex successionis to the transfer of property to the legatee will not result in the violation of the numerus clausus of rights in rem in Germany. It follows from the above that the transfer of the ownership to the legatee operates under Polish law being the lex successionis, whereas German law determines whether such a right in rem (ownership) exists and what specific rights it attributes to its holder (owner).

25. The ECJ analysis regarding the relevance of the rei sitae exemption to the legal issue at hand appears rather succinct. To begin with, the ECJ considers both legal forms of legacy, legatum per vindicationem as provided by Polish inheritance law, as well as legatum per damnationem as provided by German inheritance law, to constitute merely modalities concerning the method of the transfer of ownership of an asset. ${ }^{50}$ The ECJ emphasizes that both legal systems concerned recognize the right of ownership, as a right in rem. Therefore, the direct transfer of a property right by means of a legacy per vindicationem concerns only the arrangement by which that right in rem is transferred at the time of the testator's death. It follows that Germany is not obliged to recognize a right in rem on an asset which its law would not know. It is submitted that the ECJ considers both types of legacies to be functionally equivalent from the perspective of the SR. Profound differences regarding their legal structure are only insofar relevant as they affect the result, namely the legal transfer of an asset belonging to an estate. The ECJ does not devote any further attention to analysing the divergent legal natures of both legacies.

\subsection{Adaption Under Article 31 SR}

26. Whilst the nature of rights in rem is excluded from the scope of the SR, the adaption of rights in rem is not. The boundary between these two issues may from time to time be unclear. ${ }^{51}$ The Kubicka judgment provides an important contribution towards clarifying the boundary between the nature of rights in rem and the adaption of their content. The ECJ considers the applicability of Article 31 SR which provides for the so-called adaptation of the right in rem. The doctrine of adaptation enables Member States to preserve their own numerus clausus of rights in rem in case the applicable law of succession grants a right in rem unknown to the

50 Para. 49 of the judgment.

51 R. Frimston, in EU Regulation, p 49, note 66. 
law of the Member State where the mobile or immovable property belonging to the estate is located. As emphasized in Recital 15 SR, a Member State should not be required to recognize a right in rem relating to property located in that Member State if the right in rem in question is not known in its law. Nevertheless, that Member State has to convert such a right into a right in rem existing in its domestic property law. The application of Article 31 SR requires establishing that a right in rem which is conferred upon a beneficiary is not known in the law of the Member State concerned. ${ }^{52}$

27. In the Kubicka judgment, the Court determines the proper scope of Article 31 SR. The ECJ considers the provision of Article 31 SR to be inapplicable in the legal question at hand, and essentially deploys the same arguments as those that were already put forward in favour of not applying the exemption of right in rem to a legacy by vindication under Polish law concerning immovable property located in Germany. It is undisputed, as the ECJ holds, that German law recognizes the right of ownership with which the legatee would be vested under Polish law. ${ }^{53}$ Article 31 SR does not concern, as the ECJ goes on to explain, the method of the transfer of rights in rem, including legacies 'by vindication' or 'by damnation', but only the respect of the content of rights in rem, determined by the law governing the succession (lex causae), and their reception in the legal order of the Member State in which they are invoked (lex rei sitae). ${ }^{54}$ The Court concludes the analysis of Article 31 SR by holding that in so far as the right in rem transferred by means of legacy 'by vindication' is the right of ownership, which is recognized in German law, there is no need for the adaptation provided for in Article $31 \mathrm{SR}^{55}$ Also in this respect, the Court fully endorsed the position previously expressed in the AG's opinion.

28. It is submitted that ECJ endorses the view that Article 31 SR serves the protection of numerus clausus understood as a fixed catalogue of rights in rem. The ECJ is satisfied that German law, as well as Polish, recognizes the right of ownership (property). The Court does not consider it necessary to examine whether the right of ownership confers the same or comparable rights on the right-holder both under German and Polish law. This appears to have been implicitly assumed.

\subsection{The Registry Exemption}

29. The ECJ discusses also the relevance of registry exemption (Article 1(2)(1) SR). The Court follows explicitly the AG opinion and its narrow interpretation of registry exemption. ${ }^{56}$ According to this interpretation, the conditions ('requirements') under 
which rights in immovable or moveable property are acquired do not constitute one of the subjects excluded from the scope of the SR under registry exemption. As the ECJ emphasizes, this narrow interpretation of registry exemption is supported by two major arguments. First, the narrow interpretation of registry exemption is justified by the principle that the law governing succession should govern the succession as a whole, as provided for in Article $23 \mathrm{SR}$, particularly in Article 23(2)(e) SR, which provides that it governs the transfer to the heirs and to the legatees of the assets, rights and obligations forming part of the estate ${ }^{57}$ Second, the narrow interpretation of registry exemption is consistent with the overall objective of the SR, referred to in its Recital 7, under which it seeks to facilitate the proper functioning of the internal market by eliminating obstacles to the free movement of persons who want to claim their rights arising from a cross-border succession. ${ }^{58}$ According to that recital, in the European area of justice, citizens must be able to organize their succession in advance. Subsequently, the ECJ recognizes that applying public registry exemption in order to exclude the acquisition of ownership of an asset by legacy 'by vindication' from the scope of the SR would lead to the fragmentation of the succession, which is incompatible with the wording of Article $23 \mathrm{SR}$ and with its objective of enabling citizens to organize their succession in advance. ${ }^{59}$

30. Subsequently, in providing a procedural safeguard for a narrow interpretation of public registry exemption, the ECJ underscores the relevance of the European Certificate of Succession for facilitating the proper functioning of the internal market as far as cross-border successions are concerned. ${ }^{60}$ In particular, the ECJ refers to two crucial legal effects of Article 69 SR. ${ }^{61}$ First, the European Certificate of Succession produces direct effects in all Member States, without any special procedure being required (Article 69(1) SR). The possibility of a direct entry into a real estate registry by means of a 'foreign' certificate of succession is a major issue under the SR. ${ }^{62}$ Second, the person mentioned in the Certificate as the legatee is to be presumed to have the status mentioned in the Certificate with no conditions and/or restrictions being attached to those rights other than those stated in the Certificate (Article 69 (2) SR).

See para. 55 of the judgment.

See para. 56 of the judgment.

See para. 57 of the judgment.

On the European Certificate of Succession as a document serving for registration purposes and its interference with domestic property laws of the Member States, including the issue of the registration of the change of ownership based on legatum per vindicationem in Germany see E. GoosENs, 'A Model for the Use of the European Certificate of Succession for Property Registration', 3. European Review of Private Law 2017, pp 523-552.

61 See para. 59 of the judgment.

62 C. Baldus, 9. GPR 2012, p 313. 


\section{Mapping out the Implications of the Kubicka Judgment}

31. The major implication of the Kubicka judgment is a rather narrow interpretation of both above-mentioned exemptions: registry (Article 1(2)(1) SR) and rights in rem (Article 1(2)(k) SR). This has been discussed extensively in this contribution. Further, with a view to consolidating and extending the body of opinions regarding the SR, the Kubicka judgment gives rise to three tentative observations. First, the ECJ refused to follow a view expressed in the German judiciary and scholarship that a foreign legacy by vindication regarding an immovable property located in Germany has to be characterized as a legacy 'by damnation' under German law. On the close reading of the Kubicka judgment, this view, which was broadly held under domestic German international law of succession prior to the enactment of the SR, appears inconsistent with the objective of the SR provided in Rectial 7 and the principle of unity. Accordingly, the scholarship regarding the SR will have to take this position into account. ${ }^{63}$

32. Second, the Kubicka judgment acknowledges the central importance of the direct effects of the European Certificate of Succession in the internal market as a measure facilitating the recognition of foreign legacies by vindication in Member States whose law provides only for legacies by damnation. In his opinion regarding the Kubicka case, Advocate General Bot provides the regulatory example of the Kingdom of the Netherlands (where succession law does not admit legacies by vindication) that adapted its provisions on registration when the SR was coming into force in such a way as to allow a legatee 'by vindication' to record his right of ownership by means of the European Certificate of Succession containing a declaration that the legatee has acquired immovable property by way of a legacy. ${ }^{64}$ Apparently, the ECJ does not regard such measures as necessary to ensure the effect of the European SR, for it emphasizes the direct effects of the European Certificate of Succession in all Member States without any special procedure being required. It could be said that the European Certificate of Succession exists over and above the national systems, and should be recognized as a true European instrument. ${ }^{65}$

33. The ECJ position will have to be taken into account in interpreting German provisions on recording in rem-legal positions acquired under foreign law in real estate registries in Germany. In the German scholarship, the issue as

63 For instance J. Müller-Lukoschek, Die neue EU-Erbrechtsverordnung, para. 83; P. LaGarde, in EU Regulation, p 16; A. MachNIKOWSKA, in Unijne rozporzadzenie spadkowe, p 205.

64 Para. 68 of the AG's opinion quoting Article 27a of the Dutch Kadasterwet of 3 February 2005 (Staatsblad 2005, p 107), introduced by Article 13 Uitvoeringswet Verordening erfrecht of 5 November 2014 (Staatsblad 2014, p 430), which implements the Succession Regulation into Dutch Law.

65 G. Van Calster, European Private International Law (Oxford: Hart Publishing, 2nd edn 2016), p 338. 
to whether the European Certificate of Succession provides a sufficient basis for recording the instances of singular succession into rights on immovable property was debated with respect to $\S 35$ Section 1 (1) Grundbuchordnung. ${ }^{66}$ According to one of the views held, the European Certificate of Succession provided a sufficient proof of legitimacy for recording immovable property acquired only by means of universal succession, but not by means of singular succession as is the case with respect to legacies by vindication. Following a different view, an interpretation consistent with EU law requires 'succession' in the sense of $\S 35$ Section 1 Grundbuchordnung to include legal positions acquired by means of singular succession resulting from foreign legacies by vindication. ${ }^{67}$

34. Third, the Kubicka judgment contributes towards determining the scope of 'adaptation' under Article 31 SR. The ECJ endorses the view that there is no need for adaptation when the content of a right in rem is identical both under legi causae (here Polish law) and legi rei sitae (here German law). ${ }^{68}$ As indicated above, the ECJ appears to have implicitly assumed that the content of property right is identical in both legal systems in question. A sole difference as regards the modalities in the transfer of rights, such as the difference between legacies by vindication or by damnation, does not justify resorting to adaptation under Article $31 \mathrm{SR}$. Subsequently it is submitted that, at least until any further ECJ judgment on that matter, adaptation under Article 31 SR requires two legal positions characterized as 'in rem', yet with different legal contents. From this perspective, the position of the ECJ provides inspiration for a comparative analysis of the property law of EU Member States.

\section{Conclusion}

35. This article purported to illustrate the complex relationship between the diverging national inheritance laws of EU Members States and the EU SR with

Grundbuchordnung in der Fassung der Bekanntmachung vom 26. Mai 1994 (BGBl. I S. 1114), die zuletzt durch Artikel 11 Absatz 18 des Gesetzes vom 18. Juli 2017 (BGBl. I S. 2745) geändert worden ist. See U. Simon \& M. Buschbaum, 'Die neue EU-Erbrechtsverordnung', NJW (Neue Juristische Wochenschrift) 2012, pp 2393-2398; H. WILSCH, 'EuErbVO: Die Verordnung in der deutschen Grundbuchpraxis', ZEV (Zeitschrift für Erbrecht und Vermögensnachfolge) 2012, pp 530-532.

67 Rightly M. Fornasier, in Internationales Erbrecht, Art. 69 Succession Regulation, note 34, providing a survey of German literature on this point.

68 This view is endorsed by W. Pintens, 'Einführung in die Grundprinzipien der Erbrechtsverordnung', in M. Löhnig, D. Schwab, D. Henrich, P. Gottwald, H. Grziwotz, W. Reimann \& A. Dutta (eds), Erbfälle unter Geltung der Europäischen Erbrechtsverordnung (Bielefeld: Gieseking 2014), p (1) at 8; J.P. Sснмid, in Internationales Erbrecht, Art. 31 Succession Regulation, notes 15-16; P. Tereszkiewicz \& A. Wysocka-Bar, 'Polnische Vindikationslegate vor dem EuGH: Besprechung der Vorlagefrage des Sąd Okręgowy in Gorzów Wielkopolski', 14. GPR (Gemeinschaftsprivatrecht) 2017, p (197) at 201. 
special regard to the institute of legacy by vindication. We believe to have shown that in its Kubicka judgment, the ECJ tackled some of the central notions under the EU SR and provided important guidance for both the theory and practice of European Law of Succession. Whilst an objective of harmonizing substantive provisions of inheritance law in Europe possibly remains impossible to achieve, the EU SR may likely prove a central measure aimed at facilitating the management of succession-related matters within the European Union by both citizens concerned and officials charged with applying the law of succession. 